\title{
Impact of air pollutants on pediatric admissions for Mycoplasma pneumonia: a cross-sectional study in Shanghai, China
}

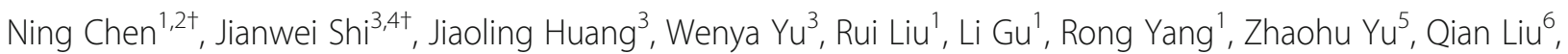
Yan Yang ${ }^{6}$, Sainan Cui ${ }^{1}$ and Zhaoxin Wang ${ }^{1,3,7^{*}}$ (1)

\begin{abstract}
Background: Children are especially vulnerable to pneumonia and the effects of air pollution. However, little is known about the impacts of air pollutants on pediatric admissions for Mycoplasma pneumonia. This study was conducted to investigate the impacts of air pollutants on pediatric hospital admissions for Mycoplasma pneumonia in Shanghai, China.

Methods: A cross-sectional design was applied to explore the association between pediatric hospital admissions and levels of air pollutants (fine particulate matter, particulate matter, ozone, sulfur dioxide, nitrogen dioxide, and carbon monoxide). Data on hospital admissions for pneumonia and levels of ambient air pollutants were obtained for the period of 2015 to 2018. Associations between pediatric admissions for Mycoplasma pneumonia and ambient air pollutants were calculated using logistic regression and described by the odds ratio and relevant 95\% confidence interval. The hysteresis effects of air pollutants from the day of hospital admission to the previous 7 days were evaluated in single-pollutant models and multi-pollutant models with adjustments for weather variables and seasonality. Lag 0 was defined as the day of hospital admission, lag 1 was defined as the day before hospital admission, and so forth.
\end{abstract}

Results: In the single-pollutant models (without adjustment for other pollutants), pediatric hospital admissions for pneumonia were positively associated with elevated concentrations of nitrogen dioxide and fine particulate matter. A $0.5 \%$ increase in daily admissions per $10-\mu \mathrm{g} / \mathrm{m}^{3}$ increase in the nitrogen dioxide level occurred at lag 1 and lag 2 , and a $0.3 \%$ increase in daily admissions per $10-\mu \mathrm{g} / \mathrm{m}^{3}$ increase in fine particulate matter occurred at lag 1 . In the multi-pollutant models, nitrogen dioxide and fine particulate matter remained significant after inclusion of particulate matter, ozone, sulfur dioxide, and carbon monoxide.

(Continued on next page)

\footnotetext{
* Correspondence: supercell002@sina.com

${ }^{\dagger}$ Ning Chen and Jianwei Shi contributed equally to this work.

'Department of Pediatrics, Shanghai Tenth People's Hospital, Tongji

University School of Medicine, Shanghai 200072, China

${ }^{3}$ School of Public Health, Shanghai Jiaotong University School of Medicine,

227 South Chongqing Rd, Shanghai 200025, China

Full list of author information is available at the end of the article
}

(C) The Author(s). 2020 Open Access This article is licensed under a Creative Commons Attribution 4.0 International License, which permits use, sharing, adaptation, distribution and reproduction in any medium or format, as long as you give appropriate credit to the original author(s) and the source, provide a link to the Creative Commons licence, and indicate if changes were made. The images or other third party material in this article are included in the article's Creative Commons licence, unless indicated otherwise in a credit line to the material. If material is not included in the article's Creative Commons licence and your intended use is not permitted by statutory regulation or exceeds the permitted use, you will need to obtain permission directly from the copyright holder. To view a copy of this licence, visit http://creativecommons.org/licenses/by/4.0/ The Creative Commons Public Domain Dedication waiver (http://creativecommons.org/publicdomain/zero/1.0/) applies to the data made available in this article, unless otherwise stated in a credit line to the data. 
(Continued from previous page)

Conclusions: This study illustrated that higher levels of nitrogen dioxide and fine particulate matter increase the risk of pediatric hospitalization for Mycoplasma pneumonia in Shanghai, China. These findings imply that the high incidence of Mycoplasma pneumonia in children in Asia might be attributed to the high concentration of specific air pollutants in Asia.

Keywords: Mycoplasma pneumonia, Air pollutants, Nitrogen dioxide, Fine particles, Children health,

\section{Background}

Pneumonia is the single largest infectious cause of death in children worldwide, accounting for $16 \%$ of all deaths of children aged $<5$ years and accounting for the deaths of 920,136 children in 2015 [1]. Mycoplasma pneumoniae is a leading causative pathogen of respiratory infections in children, accounting for as many as $30 \%$ of cases of pediatric community-acquired pneumonia [2-5]. In 2012, Miyashita et al. demonstrated that M. pneumoniae was the most prevalent pathogen in children (23\%) and adolescents (29\%) with community-acquired pneumonia, followed by Haemophilus influenzae (children, 15\%; adolescents, 10\%) and Streptococcus pneumoniae (children, 8\%; adolescents, 14\%) [6]. In 2018, Liu et al. reported that $M$. pneumoniae was detected at the highest frequency in pediatric patients hospitalized for lower respiratory tract infections (15.7\%), followed by respiratory syncytial virus (13.9\%) [7]. The underlying mechanisms of $M$. pneumoniae pneumonia are currently being investigated. Nitrogen dioxide $\left(\mathrm{NO}_{2}\right)$ has been conjectured to be associated with bacterial pneumonia. For instance, according to toxicological studies released by the United States Environmental Protection Agency, $\mathrm{NO}_{2}$ destroys epithelial cells and decreases mucociliary clearance, thereby reducing the amount of bronchial macrophages, natural killer cells, and macrophages as well as the CD4to-CD8 ratio and ultimately enhancing susceptibility to bacterial pathogens [8]. Additionally, a 2017 metaanalysis regarding the association between ambient air pollution and pediatric pneumonia showed that the pollutant-specific excess risk percentage per 10-ppb increase in gaseous pollutants was $1.4 \%$ [95\% confidence interval (CI), 0.4-2.4\%] for $\mathrm{NO}_{2}$ [9]. Apart from $\mathrm{NO}_{2}$, fine particulate matter [particles of $<2.5 \mu \mathrm{m}$ in aerodynamic diameter $\left(\mathrm{PM}_{2.5}\right)$ ] has also been speculated to be associated with pneumonia. A case-crossover study conducted in Shijiazhuang, China, showed a positive correlation between hospitalization for pneumonia and higher $\mathrm{PM}_{2.5}$ levels in both single-pollutant and multipollutant models [10]. In 2016, Patto et al. reported that a $10-\mu \mathrm{g} / \mathrm{m}^{3}$ decrease in the $\mathrm{PM}_{2.5}$ concentration was associated with 256 fewer pediatric hospital admissions for pneumonia [11]. In 2019, Croft et al. showed that increases in the interquartile range of $\mathrm{PM}_{2.5}$ during the previous week were correlated with increases in the excess rate of hospitalizations for culture-negative pneumonia $(2.5 \%$; $95 \%$ CI, $1.7-3.2)$ as well as the excess rate of hospitalizations for bacterial pneumonia (2.3\%; $95 \%$ CI, 0.3-4.3) [12]. However, the mechanisms underlying how these air pollutants cause pediatric pneumonia remain unclear.

The health of the Chinese population is threatened by the high level of air pollutants caused by industrialization and urbanization [13]. According to data published by the Chinese Ministry of Environmental Protection, most cities in China currently fail to meet the following standard daily air pollutant concentrations: $\mathrm{PM}_{2.5}$ of $35 \mu \mathrm{g} / \mathrm{m}^{3}$, particulate matter [particles of < $10 \mu \mathrm{m}$ in aerodynamic diameter $\left.\left(\mathrm{PM}_{10}\right)\right]$ of $50 \mu \mathrm{g} / \mathrm{m}^{3}$, ozone $\left(\mathrm{O}_{3}\right)$ of $100 \mu \mathrm{g} / \mathrm{m}^{3}$ (8-h average), sulfur dioxide $\left(\mathrm{SO}_{2}\right)$ of $50 \mu \mathrm{g} / \mathrm{m}^{3}, \mathrm{NO}_{2}$ of $80 \mu \mathrm{g} / \mathrm{m}^{3}$, and carbon monoxide (CO) of $4 \mathrm{mg} / \mathrm{m}^{3}$ [14]. Additionally, some of the annual air pollution levels (2015-2018) have exceeded the recommended standards proposed by the World Health Organization, with a $\mathrm{PM}_{2.5}$ of $44.75 \mu \mathrm{g} / \mathrm{m}^{3}$ (higher than the recommended level of $10 \mu \mathrm{g} / \mathrm{m}^{3}$ ), $\mathrm{PM}_{10}$ of $78.75 \mu \mathrm{g} / \mathrm{m}^{3}$ (far beyond the recommendation of $20 \mu \mathrm{g} / \mathrm{m}^{3}$ ), and $\mathrm{O}_{3}$ level of $143 \mu \mathrm{g} / \mathrm{m}^{3}$ (higher than the recommendation of $100 \mu \mathrm{g} / \mathrm{m}^{3}$ ). The annual level of $\mathrm{SO}_{2}$ in China from 2015 to 2018 was $19.75 \mu \mathrm{g} / \mathrm{m}^{3}$ and that of $\mathrm{CO}$ was $1.8 \mathrm{mg} / \mathrm{m}^{3}$, while the level of $\mathrm{NO}_{2}$ was $30 \mu \mathrm{g} / \mathrm{m}^{3}$ (slightly lower than $40 \mu \mathrm{g} / \mathrm{m}^{3}$ ).

As a rapidly urbanizing city in the Yangtze River Delta in China, Shanghai has been experiencing problems caused by environmental pollution with concentrations of main air pollutants far exceeding the national standards for years. The major sources of air pollution are automobile exhaust emissions and industrial waste gases. According to the China Mobile Source Environmental Management Annual Report (2019), mobile sources have become the major sources of air pollution, especially $\mathrm{PM}_{2.5}$, in large and medium-sized cities such as Shanghai, Beijing, and Shenzhen. Children are more vulnerable to the respiratory health effects of ambient air pollution because of their frequent exposure to outdoor air, high respiratory rate, narrow airways, and developing lungs and immune systems [15]. Although many studies have demonstrated the potential adverse health effects attributed to air pollutants, including cardiovascular mortality [16], asthma exacerbation [17], and restricted activity 
[18], few empirical studies have proven the relationship between levels of air pollutants and Mycoplasma pneumonia in the pediatric population.

Because of the lack of empirical studies regarding the influence of air pollutants on Mycoplasma pneumonia among children, we performed the present crosssectional study to examine the impacts of air pollutants on hospital admissions for Mycoplasma pneumonia and elucidate the hysteresis effects of air pollutants among children aged 1 to 14 years in Shanghai, a large modern city in southeast China.

\section{Methods}

\section{Study design and setting}

In this descriptive cross-sectional study, we investigated variations in pediatric Mycoplasma pneumonia in relation to ambient air pollutant levels in Shanghai throughout a 4-year period (2015-2018). Shanghai is one of the largest metropolitan cities in the world. Its gross domestic product ranks first in China, and its population in 2017 was approximately 24.18 million. The city enjoys a subtropical humid monsoon climate, and the mean annual temperature was $18.34{ }^{\circ} \mathrm{C} \pm 8.71{ }^{\circ} \mathrm{C}$ from 2015 to 2018.

\section{Data collection}

We extracted data on all hospital admissions of inpatients aged 1 to 14 years who were admitted with a primary diagnosis of pneumonia (International Classification of Diseases, 11th revision code: CA40.04) from January 2015 through December 2018. Patient data were obtained from the Pediatric Department of Shanghai Tenth People's Hospital, one of the largest tertiary general hospitals in Jing'an District of Shanghai. This hospital receives a large proportion of the pediatric inpatients in this area. Data from 2569 eligible patients were obtained from pediatric admissions for pneumonia in this hospital. Among them, 693 patients were diagnosed with Mycoplasma pneumonia. Mycoplasma pneumonia antibody was detected by colloidal gold assay. Age, sex, and date of admission were extracted from the medical records.

Data on the following air pollutants in Shanghai were obtained from the website of the Shanghai Environmental Monitoring Center: $\mathrm{PM}_{2.5}, \mathrm{PM}_{10}, \mathrm{O}_{3}, \mathrm{SO}_{2}, \mathrm{NO}_{2}$, and $\mathrm{CO}$. These data were recorded every 1,8 , or $24 \mathrm{~h}$. The 24-h average levels of all of these pollutants except $\mathrm{O}_{3}$ (maximum 8-h average level) were applied in our analysis. Nine air quality monitoring stations were employed by the Shanghai Municipal Bureau of Ecology and Environment. The sampling points were located in Putuo District, Yangpu District, Huangpu District, Hongkou District, Jing'an District, Xuhui District, and Pudong New area. The exposure levels were calculated as the mean monitoring data of the nine stations and were disclosed by the Shanghai Environmental Monitoring Center every $1 \mathrm{~h}$ and every $24 \mathrm{~h}$ separately.

Daily temperature data in Shanghai were collected from the Shanghai Meteorological Service. Monthly relative humidity data were compiled from the China Statistical Yearbook by the National Bureau of Statistics.

\section{Study variables}

The results of $M$. pneumoniae immunoglobulin $\mathrm{M}$ detection were considered as the dependent variable $(M$. pneumoniae-positive =1, M. pneumoniae-negative $=0$ ). The control variables were age, sex, and season of admission.

We considered several independent variables, including pollutants and climatic variables, for the logistic regression model. The concentrations of the main air pollutants were calculated using 24-h averages. We calculated the monthly averages for further analysis. The unit of measurement for $\mathrm{PM}_{2.5}, \mathrm{PM}_{10}, \mathrm{O}_{3}, \mathrm{SO}_{2}$, and $\mathrm{NO}_{2}$ was $\mu \mathrm{g} / \mathrm{m}^{3}$, and the unit of measurement for $\mathrm{CO}$ was $\mathrm{mg} / \mathrm{m}^{3}$. Time was considered to be a potential confounder because of its mixed relationship with air pollutants. Thus, the models included indicator variables for season (spring, summer, autumn, and winter) and lag days of a week (7 days). The daily mean temperature and monthly relative humidity were also included in the analysis.

\section{Statistical analysis}

A time-stratified approach was utilized to select control days. For the exposure metrics, the air pollutant levels of every hospital admission day were compared with those of the whole week before the date of admission. The impacts on pediatric hospital admission for pneumonia were assessed with lags from day 0 to the previous 7 days. Lag 0 was defined as the day of hospital admission, lag 1 was defined as the day before hospital admission, and so forth.

Descriptive statistical analyses of all variables were performed to characterize the features of the patients, air pollutants, and meteorological data separately. Associations between pediatric hospital admissions for pneumonia and ambient air pollutant variables of interest were calculated using logistic regression, described by the odds ratio (OR) and relevant $95 \%$ CI. To evaluate the impacts of atmospheric pollutants on pediatric hospital admissions for Mycoplasma pneumonia, single-pollutant and multi-pollutant models were used to calculate the associations between them. Single-pollutant models were initially employed to evaluate the effects of each air pollutant. Then multi-pollutant models including all the six pollutants were also performed to present the condition of mixed states of these pollutants. Concentrations of air 
pollutants were included in the models as continuous variables. The model controlled for meteorological variables that might function as the prime potential confounding factors (daily mean temperature and relative humidity). We then calculated the elevated risk of pediatric admission for Mycoplasma pneumonia with the corresponding $10-\mu \mathrm{g} / \mathrm{m}^{3}$ or $1-\mathrm{mg} / \mathrm{m}^{3}$ increase the air pollutant concentration. Stratified analyses of pollutant exposure on the basis of age, sex (male or female), and season (spring: March-May; summer: June-August; autumn: September-November; winter: December-February) were applied to estimate the effect modification.

All statistical analyses were performed using IBM SPSS Statistics version 21 (IBM Corp., Armonk, NY, USA). The criterion for significance was set at $p<0.05$.

\section{Results}

\section{Descriptive statistical analysis}

A total of 2569 admissions to the Pediatric Department of Shanghai Tenth People's Hospital for M. pneumoniae detection occurred from 2015 through 2018. The characteristics of the pediatric hospital admissions categorized by sex, age, and season are presented in Table 1 . Among the 2569 admissions, 1281 (49.86\%) patients were male and 1288 (50.14\%) were female. The children's ages ranged from 1 to 14 years (median, 4 years). In total, 693 patients were diagnosed with Mycoplasma pneumonia (Table 1). No significant difference was found in age or sex between children who were and were not diagnosed with pneumonia ( $p>0.05$ for both). However, significant differences were found in the season of pediatric hospital admissions between the two groups ( $p<0.05$ for all seasons).

The air pollutant measurements in Shanghai covered a span of 4 years (2015-2018) and encompassed 1461 daily measurements (shown in Table 2), as well as the relevant 4-year weather conditions. As shown in Table 2, during the study period of January 2015 through December 2018, the mean daily ambient concentrations of $\mathrm{PM}_{2.5}$, $\mathrm{PM}_{10}, \mathrm{O}_{3}, \mathrm{SO}_{2}$, and $\mathrm{NO}_{2}$ in Shanghai were $42.93 \pm 28.95$, $58.60 \pm 32.65,105.04 \pm 45.93,13.23 \pm 6.89$, and $43.62 \pm$ $20.03 \mu \mathrm{g} / \mathrm{m}^{3}$, respectively, and that of $\mathrm{CO}$ was $0.77 \pm$ $0.27 \mathrm{mg} / \mathrm{m}^{3}$.

The daily measurements of ambient air pollutants during the 4-year period revealed that the $\mathrm{PM}_{2.5}, \mathrm{PM}_{10}, \mathrm{O}_{3}$, $\mathrm{NO}_{2}, \mathrm{SO}_{2}$, and $\mathrm{CO}$ concentrations surpassed the allowed limit in Shanghai on 725 days (49.62\%), 717 days (49.08\%), 675 days $(46.20 \%), 83$ days $(5.68 \%), 8$ days $(0.55 \%)$, and 0 days $(0.00 \%)$, respectively.

Pearson's correlation coefficients among the air pollutants, daily mean temperature, and monthly relative humidity in Shanghai are displayed in Table 3. Significant correlations were found among the air pollutants in Shanghai, especially between $\mathrm{PM}_{2.5}$ and $\mathrm{PM}_{10}(\mathrm{r}=0.864)$, $\mathrm{PM}_{2.5}$ and $\mathrm{CO}(\mathrm{r}=0.863), \mathrm{PM}_{10}$ and $\mathrm{SO}_{2}(\mathrm{r}=0.745)$, $\mathrm{PM}_{2.5}$ and $\mathrm{SO}_{2}(\mathrm{r}=0.742), \mathrm{NO}_{2}$ and $\mathrm{CO}(\mathrm{r}=0.739), \mathrm{PM}_{10}$ and $\mathrm{CO}(\mathrm{r}=0.726), \mathrm{SO}_{2}$ and $\mathrm{CO}(\mathrm{r}=0.714), \mathrm{NO}_{2}$ and $\mathrm{PM}_{2.5}(\mathrm{r}=0.698), \mathrm{NO}_{2}$ and $\mathrm{PM}_{10}(\mathrm{r}=0.648)$, and $\mathrm{NO}_{2}$ and $\mathrm{SO}_{2}(\mathrm{r}=0.637)$. A conspicuous elevation in the daily air pollutant levels was observed with reductions in the daily mean temperature and monthly relative humidity.

\section{Association between various air pollutants and Mycoplasma pneumonia in children}

In the single-pollutant models, the most notable lag periods for $\mathrm{NO}_{2}$ were lag 0 and lag $1(\mathrm{OR}=1.005,95 \%$ $\mathrm{CI}=1.000-1.010)$, and the most apparent lag time for $\mathrm{PM}_{2.5}$ was lag $1(\mathrm{OR}=1.003,95 \% \mathrm{CI}=1.000-1.006)$. The single-pollutant model showed a $0.5 \%(95 \% \mathrm{CI}, 1.000$ 1.010) enhanced risk of pediatric hospital admissions for

Table 1 Distribution of pediatric hospital admissions for pneumonia based on patient characteristics and season $(n=2569)$

\begin{tabular}{|c|c|c|c|c|c|c|}
\hline \multirow[t]{2}{*}{ Characteristics } & \multicolumn{2}{|c|}{ MP-Positive } & \multicolumn{2}{|c|}{ MP-Negative } & \multicolumn{2}{|c|}{ Total Admission } \\
\hline & Number & Percentage(\%) & Number & Percentage(\%) & Number & Percentage(\%) \\
\hline \multicolumn{7}{|l|}{ Gender } \\
\hline Male & 331 & 47.76 & 950 & 50.64 & 1281 & 49.86 \\
\hline Female & 362 & 52.24 & 926 & 49.36 & 1288 & 50.14 \\
\hline \multicolumn{7}{|l|}{ Age (year) } \\
\hline $1-4$ & 249 & 35.93 & 1065 & 56.77 & 1314 & 51.15 \\
\hline $5-14$ & 444 & 64.07 & 811 & 43.23 & 1255 & 48.85 \\
\hline \multicolumn{7}{|l|}{ Season } \\
\hline Spring & 156 & 22.51 & 489 & 26.07 & 645 & 25.11 \\
\hline Summer & 111 & 16.02 & 241 & 12.85 & 352 & 13.70 \\
\hline Autumn & 210 & 30.30 & 502 & 26.76 & 712 & 27.72 \\
\hline Winter & 216 & 31.17 & 644 & 34.33 & 860 & 33.48 \\
\hline Total & 693 & 100.00 & 1876 & 100.00 & 2569 & 100.00 \\
\hline
\end{tabular}


Table 2 Distribution of daily ambient concentrations and daily temperatures in Shanghai, China, 2015-2018 ( $n=1461)$

\begin{tabular}{llllllll}
\hline Variable & $\mathrm{X} \pm \mathrm{S}$ & Min & $\mathrm{P} 25$ & $\mathrm{P} 50$ & $\mathrm{P75}$ & Max & IQR \\
\hline $\mathrm{PM}_{2.5}\left(\mu \mathrm{g} / \mathrm{m}^{3}\right)$ & $42.93 \pm 28.95$ & 5.00 & 22.00 & 35.00 & 55.00 & 218.00 & 33.00 \\
$\mathrm{PM}_{10}\left(\mu \mathrm{g} / \mathrm{m}^{3}\right)$ & $58.60 \pm 32.65$ & 8.00 & 36.00 & 50.00 & 74.00 & 250.00 & 38.00 \\
$\mathrm{O}_{3}\left(\mu \mathrm{g} / \mathrm{m}^{3}\right)$ & $105.04 \pm 45.93$ & 11.00 & 73.00 & 97.00 & 131.00 & 286.00 & 58.00 \\
$\mathrm{SO}_{2}\left(\mu \mathrm{g} / \mathrm{m}^{3}\right)$ & $13.23 \pm 6.89$ & 4.00 & 9.00 & 11.00 & 15.00 & 75.00 & 6.00 \\
$\mathrm{NO}_{2}\left(\mu \mathrm{g} / \mathrm{m}^{3}\right)$ & $43.62 \pm 20.03$ & 6.00 & 29.00 & 40.00 & 55.00 & 139.00 \\
$\mathrm{CO}\left(\mathrm{mg} / \mathrm{m}^{3}\right)$ & $0.77 \pm 0.27$ & 0.40 & 0.60 & 0.70 & 0.90 & 2.00 \\
$\mathrm{~T}\left({ }^{\circ} \mathrm{C}\right)$ & $18.43 \pm 8.71$ & -5.00 & 11.00 & 19.50 & 25.50 & 35.50 \\
$\mathrm{H}(\%)$ & $70.77 \pm 6.31$ & 53.00 & 66.00 & 71.00 & 75.00 & 83.00 \\
\hline $\mathrm{X}(\%)$ & & &
\end{tabular}

$\mathrm{X}$, mean value; $\mathrm{S}$, standard deviation; Min, minimum value; Max, maximum value; IQR, interquartile range; $\mathrm{PM}_{2.5}$, fine particulate matter; $\mathrm{PM}_{10}$, particulate matter; $\mathrm{O}_{3}$, ozone; $\mathrm{SO}_{2}$, sulfur dioxide; $\mathrm{NO}_{2}$, nitrogen dioxide; $\mathrm{CO}$, carbon monoxide; $\mathrm{T}$, daily mean temperature; $\mathrm{H}$, relative humidity

Mycoplasma pneumonia per $10-\mu \mathrm{g} / \mathrm{m}^{3}$ increase in the $\mathrm{NO}_{2}$ level on lag 0 . The model showed an increase of $0.5 \%$ on lag 1 as well. The model also showed a $0.3 \%$ (95\% CI, 1.000-1.006) enhanced risk of pediatric hospital admissions for Mycoplasma pneumonia per 10- $\mu \mathrm{g} /$ $\mathrm{m}^{3}$ increase in the $\mathrm{PM}_{2.5}$ concentration on lag 1 (Table 4). The association between $\mathrm{PM}_{10}$ and pediatric hospital admissions for Mycoplasma pneumonia was not significant in single-pollutant models $(p>0.5) . \mathrm{O}_{3}, \mathrm{SO}_{2}$, and $\mathrm{CO}$ exhibited paradoxical patterns in the singlepollutant models.

Multi-pollutant models were applied to ensure the stability of the latent effects of $\mathrm{NO}_{2}$ and $\mathrm{PM}_{2.5}$. Both $\mathrm{NO}_{2}$ and $\mathrm{PM}_{2.5}$ remained significantly associated with pediatric hospital admissions for Mycoplasma pneumonia after inclusion of the other pollutants $\left(\mathrm{PM}_{10}, \mathrm{O}_{3}\right.$, $\mathrm{SO}_{2}$, and $\mathrm{CO}$ ) into the models. The multi-pollutant models showed a positive association between $\mathrm{NO}_{2}$ and pediatric hospital admissions for Mycoplasma pneumonia on lag 0 , lag 2 , lag 3 , and lag 4 after controlling for meteorological variables. A positive association was found between $\mathrm{PM}_{2.5}$ and pediatric hospital admissions for Mycoplasma pneumonia on lag 1 (Table 5). The association between $\mathrm{PM}_{10}$ and pediatric hospital admissions for Mycoplasma pneumonia was also not significant in multi-pollutant models $(p>0.5)$. The other pollutants in the multi-pollutant models were not risk factors in our analysis.

\section{Discussion}

This study is one of the few to investigate the association between exposure to air pollutants and pediatric hospital admissions for Mycoplasma pneumonia, especially in a typically populous metropolis (Shanghai, China). Our data revealed that the $\mathrm{NO}_{2}$ and $\mathrm{PM}_{2.5}$ concentrations were positively associated with the increases in daily pediatric hospital admissions for Mycoplasma pneumonia with hysteresis effects in both single-pollutant and multi-pollutant models.

Previous investigations showed variations in the associations between hospital admissions and the lag times of atmospheric pollutant levels (ranging from the day of admission to the previous 7 days). We found very few studies with longer lag times. Therefore, we investigated the air quality measures with a 7-day lag time. Most of the statistically significant positive associations were found between the 0-day to 4-day lagged air quality metrics (especially $\mathrm{NO}_{2}$ and $\mathrm{PM}_{2.5}$ ) and pediatric Mycoplasma pneumonia. No obvious associations were found between $\mathrm{PM}_{10}, \mathrm{SO}_{2}$, or $\mathrm{CO}$ and pediatric Mycoplasma

Table 3 Pearson's correlation coefficients among air pollutants in Shanghai, China, 2015-2018 $(n=1461)$

\begin{tabular}{lllllllll}
\hline Variable & $\mathrm{PM}_{2.5}$ & $\mathrm{PM}_{10}$ & $\mathrm{O}_{3}$ & $\mathrm{SO}_{2}$ & $\mathrm{NO}_{2}$ & $\mathrm{CO}$ & $\mathrm{T}$ \\
\hline $\mathrm{PM}_{2.5}$ & 1.000 & $0.864^{* *}$ & $0.058^{*}$ & $0.742^{* *}$ & $0.698^{* *}$ & $0.863^{* *}$ & $-0.293^{* *}$ & 0.014 \\
$\mathrm{PM}_{10}$ & - & 1.000 & $0.136^{* *}$ & $0.745^{* *}$ & $0.648^{* *}$ & $0.726^{* *}$ & $-0.248^{* *}$ & $-0.065^{*}$ \\
$\mathrm{O}_{3}$ & - & - & 1.000 & $-0.081^{* *}$ & $-0.199^{* *}$ & $-0.131^{* *}$ & $0.537^{* *}$ & -0.015 \\
$\mathrm{SO}_{2}$ & - & - & - & 1.000 & $0.637^{* *}$ & $0.714^{* *}$ & $-0.415^{* *}$ & 0.044 \\
$\mathrm{NO}_{2}$ & - & - & - & - & 1.000 & $0.739^{* *}$ & $-0.434^{* *}$ & $-0.068^{* *}$ \\
$\mathrm{CO}$ & - & - & - & - & - & -1.000 & $-0.333^{* *}$ & $0.111^{* *}$ \\
$\mathrm{~T}$ & - & - & - & - & - & - & 1.000 & $0.233^{* *}$ \\
$\mathrm{H}$ & - & - & - & - & - & - & - & - \\
\hline
\end{tabular}

**Significant at $p<0.01$. *Significant at $\mathrm{p}<0.05$. $\mathrm{PM}_{2.5}$, fine particulate matter; $\mathrm{PM}_{10}$, particulate matter; $\mathrm{O}_{3}$, ozone; $\mathrm{SO}_{2}$, sulfur dioxide; $\mathrm{NO}_{2}$, nitrogen dioxide; $\mathrm{CO}_{1}$ carbon monoxide; $\mathrm{T}$, daily mean temperature; $\mathrm{H}$, monthly relative humidity. 
Table 4 Association between daily concentrations of atmospheric pollutants and pediatric hospital admissions for Mycoplasma pneumonia in Shanghai, China, 2015-2018: single-pollutant models $(n=2569)$

\begin{tabular}{|c|c|c|c|c|c|c|c|c|}
\hline & & & & OR & $95 \% \mathrm{Cl}$ & & & \\
\hline $\begin{array}{l}\text { Air } \\
\text { pollutants }\end{array}$ & Lag0 & Lag1 & Lag2 & Lag3 & Lag4 & Lag5 & Lag6 & Lag7 \\
\hline $\mathrm{PM}_{2.5}$ & $\begin{array}{l}1.002(0.998- \\
1.005)\end{array}$ & $\begin{array}{l}1.003(1.000- \\
1.006)\end{array}$ & $\begin{array}{l}0.998(0.995- \\
1.002)\end{array}$ & $\begin{array}{l}0.998(0.994- \\
1.001)\end{array}$ & $\begin{array}{l}0.998(0.995- \\
1.002)\end{array}$ & $\begin{array}{l}1.001(0.997- \\
1.004)\end{array}$ & $\begin{array}{l}1.000(0.996- \\
1.003)\end{array}$ & $\begin{array}{l}1.001(0.998- \\
1.005)\end{array}$ \\
\hline $\mathrm{PM}_{10}$ & $\begin{array}{l}1.001(0.998- \\
1.004)\end{array}$ & $\begin{array}{l}1.001(0.998- \\
1.004)\end{array}$ & $\begin{array}{l}0.999(0.996- \\
1.002)\end{array}$ & $\begin{array}{l}0.998(0.995- \\
1.001)\end{array}$ & $\begin{array}{l}0.998(0.995- \\
1.001)\end{array}$ & $\begin{array}{l}1.001(0.998- \\
1.003)\end{array}$ & $\begin{array}{l}0.998(0.995- \\
1.002)\end{array}$ & $\begin{array}{l}1.001(0.998- \\
1.004)\end{array}$ \\
\hline $\mathrm{O}_{3}$ & $\begin{array}{l}0.997^{*}(0.994- \\
1.000)\end{array}$ & $\begin{array}{l}0.996 * \text { (0.993- } \\
0.999)\end{array}$ & $\begin{array}{l}0.998(0.995- \\
1.000)\end{array}$ & $\begin{array}{l}1.000(0.997- \\
1.002)\end{array}$ & $\begin{array}{l}1.000(0.997- \\
1.003)\end{array}$ & $\begin{array}{l}1.002(1.000- \\
1.005)\end{array}$ & $\begin{array}{l}0.998(0.996- \\
1.001)\end{array}$ & $\begin{array}{l}0.999(0.997- \\
1.002)\end{array}$ \\
\hline $\mathrm{SO}_{2}$ & $\begin{array}{l}0.982(0.962- \\
1.002)\end{array}$ & $\begin{array}{l}0.986(0.966- \\
1.007)\end{array}$ & $\begin{array}{l}0.978(0.959- \\
0.998)\end{array}$ & $\begin{array}{l}0.968(0.949- \\
0.988)\end{array}$ & $\begin{array}{l}0.967^{*}(0.947- \\
0.988)\end{array}$ & $\begin{array}{l}0.984(0.965- \\
1.005)\end{array}$ & $\begin{array}{l}0.978(0.958- \\
0.997)\end{array}$ & $\begin{array}{l}0.978(0.959- \\
0.998)\end{array}$ \\
\hline $\mathrm{NO}_{2}$ & $\begin{array}{l}1.005^{*}(1.000- \\
1.010)\end{array}$ & $\begin{array}{l}1.005^{*}(1.000- \\
1.010)\end{array}$ & $\begin{array}{l}1.002(0.997- \\
1.006)\end{array}$ & $\begin{array}{l}1.000(0.995- \\
1.005)\end{array}$ & $\begin{array}{l}1.000(0.995- \\
1.005)\end{array}$ & $\begin{array}{l}1.001(0.996- \\
1.006)\end{array}$ & $\begin{array}{l}1.000(0.995- \\
1.005)\end{array}$ & $\begin{array}{l}1.001(0.996- \\
1.005)\end{array}$ \\
\hline $\mathrm{CO}$ & $\begin{array}{l}1.046(0.721- \\
1.517)\end{array}$ & $\begin{array}{l}1.232(0.850- \\
1.786)\end{array}$ & $\begin{array}{l}0.735(0.501- \\
1.076)\end{array}$ & $\begin{array}{l}0.696(0.481- \\
1.008)\end{array}$ & $\begin{array}{l}0.689^{*}(0.480- \\
0.990)\end{array}$ & $\begin{array}{l}0.939(0.651- \\
1.355)\end{array}$ & $\begin{array}{l}0.873(0.592- \\
1.289)\end{array}$ & $\begin{array}{l}1.006(0.685- \\
1.477)\end{array}$ \\
\hline
\end{tabular}

Adjusted for sex, age, season, daily mean temperature, and relative monthly humidity

$\mathrm{OR}$ odds ratio; $\mathrm{Cl}$ confidence interval; $P M_{2.5}$ fine particulate matter; $P M_{10}$ particulate matter; $\mathrm{O}_{3}$ ozone; $\mathrm{SO}_{2}$ sulfur dioxide; $\mathrm{NO}_{2}$ nitrogen dioxide; $C \mathrm{O}$ carbon monoxide

Lag 0, day of hospital admission; Lag 1, day before hospital admission; and so forth

*Significant at $p<0.05$

pneumonia for any of the 7-day lags in this study. A pronounced association was detected between $\mathrm{NO}_{2}$ exposure and pediatric hospital admissions for Mycoplasma pneumonia, revealing $\mathrm{NO}_{2}$ exposure as a risk factor on lag 0 and lag 1 in the single-pollutant models and on lag 0 , $\operatorname{lag} 2$, lag 3 , and lag 4 in the multi-pollutant models. In 2016, de Souza and Nascimento reported $\mathrm{NO}_{2}$ as a risk factor for pediatric hospitalization for pneumonia on lag 1 and lag 5 , with a $10-\mu \mathrm{g} / \mathrm{m}^{3}$ increase in the concentration of this pollutant leading to a $7 \%$ elevation in

Table 5 Association between daily concentrations of atmospheric pollutants and pediatric hospital admissions for Mycoplasma pneumonia in Shanghai, China, 2015-2018: multipollutant models $(n=2569)$

\begin{tabular}{llllll}
\hline & $\mathrm{NO}_{2}{ }^{\mathrm{a}}$ & & & $\mathrm{PM}_{2.5}{ }^{\mathrm{a}}$ & \\
\cline { 2 - 3 } & $\mathrm{OR}$ & $95 \% \mathrm{Cl}$ & & $\mathrm{OR}$ & $95 \% \mathrm{Cl}$ \\
\hline Lag0 & $1.010^{*}$ & $1.003-1.018$ & & 1.006 & $0.998-1.014$ \\
Lag1 & 1.005 & $0.997-1.012$ & & $1.009^{*}$ & $1.000-1.017$ \\
Lag2 & $1.009^{*}$ & $1.001-1.016$ & & 1.003 & $0.994-1.011$ \\
Lag3 & $1.009^{*}$ & $1.002-1.017$ & & 1.002 & $0.994-1.011$ \\
Lag4 & $1.009^{*}$ & $1.002-1.016$ & & 1.006 & $0.997-1.015$ \\
Lag5 & 1.005 & $0.998-1.012$ & & 1.000 & $0.992-1.008$ \\
Lag6 & 1.003 & $0.995-1.010$ & & 1.006 & $0.997-1.015$ \\
Lag7 & 1.001 & $0.993-1.008$ & & 1.004 & $0.995-1.013$ \\
\hline Adjust & 1.00 & & & &
\end{tabular}

Adjusted for sex, age, season, daily mean temperature, and relative monthly humidity

$O R$ odds ratio; $\mathrm{Cl}$ confidence interval; $\mathrm{NO}_{2}$ nitrogen dioxide; $P M_{2.5}$ fine particulate matter

In the multi-pollutant model, which includes $\mathrm{PM}_{2.5}, \mathrm{PM}_{10}, \mathrm{O}_{3}, \mathrm{SO}_{2}, \mathrm{NO}_{2}$, and $\mathrm{CO}$

*Significant at $p<0.05$ the relative risk [19]. In 2018, Carvalho et al. examined more than 150 pediatric hospital admissions for respiratory diseases including pneumonia, bronchitisbronchiolitis, asthma, and laryngitis-tracheitis. They found that $\mathrm{NO}_{2}$ was a significant risk factor on lag 2 and lag 3 in a single-pollutant model. They also found a positive association on lags 2 to 5 and lag 7 with a relative risk of 1.05 to 1.09 per $10-\mu \mathrm{g} / \mathrm{m}^{3}$ increase in the $\mathrm{NO}_{2}$ concentration [20]. A meta-analysis of 10 European birth cohorts within the ESCAPE project detected consistent evidence that the combined adjusted ORs for pneumonia were significantly higher for $\mathrm{NO}_{2}(\mathrm{OR}=1.30$ and $95 \% \mathrm{CI}=1.02-1.65$ per $10-\mu \mathrm{g} / \mathrm{m}^{3}$ increase in $\mathrm{NO}_{2}$ ) in early childhood [21]. In 2014, Lu et al. reported a significant association between an elevated risk of pneumonia in children and increased levels of $\mathrm{NO}_{2}(\mathrm{OR}=1.157$, $95 \% \mathrm{CI}=1.121-1.195)$ as well as the episode day $(\mathrm{OR}=$ $1.038,95 \% \mathrm{CI}=1.024-1.051$ ) [22]. In accordance with our findings, the results of a study conducted in Jinan showed a positive association between the $\mathrm{NO}_{2}$ concentration and pediatric hospital admission for pneumonia, with a higher mean daily $\mathrm{NO}_{2}$ concentration (55.2 \pm $22.4 \mu \mathrm{g} / \mathrm{m}^{3}$ ) than in our study [23]. Notably, the mean daily $\mathrm{NO}_{2}$ concentration in Shanghai $(43.62 \pm 20.03 \mu \mathrm{g} /$ $\left.\mathrm{m}^{3}\right)$ was slightly lower than that in Changsha $\left(46 \mu \mathrm{g} / \mathrm{m}^{3}\right)$, while the study carried out in Changsha failed to discern an association between exposure to $\mathrm{NO}_{2}$ and pediatric hospital admissions for pneumonia [24].

The latent mechanisms by which ambient air pollution threatens the respiratory health of children have not been elucidated until now. As a free radical, $\mathrm{NO}_{2}$ can give rise to injuries and inflammation by means of 
depleting tissue antioxidant defenses. Numerous experimental studies have indicated that $\mathrm{NO}_{2}$ exerts a range of detrimental effects on lung metabolism, structure, function, inflammation, and host defenses against pulmonary infections. Berglund et al. reported that lung susceptibility to bacterial and viral infections is increased due to exposure to $\mathrm{NO}_{2}$, which may provide a breeding bed for M. pneumoniae [25]. Acute exposure to higher levels of $\mathrm{NO}_{2}$ can attenuate pulmonary bactericidal activity and alveolar macrophage function, suggesting that specific host defense functions can be obstructed due to $\mathrm{NO}_{2}$. Moreover, investigations have detected nitric and nitrous acids or their salts in the blood and urine, implying that $\mathrm{NO}_{2}$ or its chemical products can remain within the lung for prolonged periods. This might be a conceivable explanation for the observed lag effects of $\mathrm{NO}_{2}$ in the present study [26, 27]. As one of the main anthropogenic emission approaches, the combustion processes in mobile sources (internal combustion engines in vehicles and ships) account for one of the major sources of $\mathrm{NO}_{2}$ in Shanghai. Rush-hour traffic emissions of $\mathrm{NO}_{2}$ can reach relatively high levels even exceeding $940 \mu \mathrm{g} / \mathrm{m}^{3}$ [28]. Svartengren et al. reported that the $\mathrm{NO}_{2}$ concentration inside a car in a road tunnel during rush hour could reach 179 to $668 \mu \mathrm{g} / \mathrm{m}^{3}$ [29]. Living in such a trafficclogged city in China, the population in Shanghai can inevitably suffer from the air pollution caused by automobile exhaust emissions. For children, who are particularly sensitive to the external environment, the risk of $\mathrm{Myco}$ plasma pneumonia associated with air pollution is undoubtedly increased. This can be attributed to their immature immune system and lung function, as well as their high respiratory rates.

Our study also showed that the average $\mathrm{PM}_{2.5}$ concentration exceeded $35 \mu \mathrm{g} / \mathrm{m}^{3}$ (24-h limit in China), which may trigger notably deleterious health effects in children with Mycoplasma pneumonia. Few similar associations have been reported to date. In 2010, Belleudi et al. found that a $10-\mu \mathrm{g} / \mathrm{m}^{3}$ increase in the $\mathrm{PM}_{2.5}$ concentration was positively associated with a $3.04 \%(95 \% \mathrm{CI}=0.83-5.30)$ increase in hospital admissions for lower respiratory tract infections on lag 3 [30]. In 2016, Patto et al. reported that a $10-\mu \mathrm{g} / \mathrm{m}^{3}$ increase in the $\mathrm{PM}_{2.5}$ concentration led to a significant elevation of 25 to $28 \mathrm{ppb}$ in the risk of hospitalization for pneumonia among children 4 and 5 days after exposure. The data in the present study showed a $0.9 \%$ increase in pediatric hospital admissions for $M$. pneumoniae infection per $-10 \mu \mathrm{g} / \mathrm{m}^{3}$ increase in the $\mathrm{PM}_{2.5}$ concentration on lag 1 in the multi-pollutant models. In our study, it was found that Pearson's correlation coefficient of $\mathrm{PM}_{2.5}$ and $\mathrm{PM}_{10}$ was high. However, the results of the single-pollutant models showed a $0.3 \%$ (95\% CI, 1.000-1.006) enhanced risk of pediatric hospital admissions for Mycoplasma pneumonia per 10- $\mu \mathrm{g} /$ $\mathrm{m}^{3}$ increase in the $\mathrm{PM}_{2.5}$ concentration on lag 1 , while $\mathrm{PM}_{10}$ did not appear to be associated with pediatric hospital admissions for Mycoplasma pneumonia. Although $\mathrm{PM}_{10}$ contains not only particles with an aerodynamic diameter of 0.1 to $2.5 \mu \mathrm{m}$ but also coarse PM with an aerodynamic diameter of 2.5 to $10 \mu \mathrm{m}, \mathrm{PM}_{10}$ still had no association with pediatric hospital admissions for $\mathrm{Myco}$ plasma pneumonia in multi-pollutant models, indicating that the core element affecting pediatric hospital admissions for Mycoplasma pneumonia is fine PM $\left(\mathrm{PM}_{2.5}\right)$ rather than $\mathrm{PM}_{10}$.

Numerous studies have revealed that inhaled particulate matter has detrimental consequences not only for the lungs but also for other organs and tissues. Controlled-exposure studies involving humans and animals have implied that ambient particles might have direct influences on the respiratory tract. Adverse reactions such as the occurrence of inflammation, attenuation of pulmonary defense function, and deterioration of preexisting respiratory diseases may be attributed to the above-mentioned impacts [31]. The potential mechanisms of the adverse respiratory impacts of exposure to $\mathrm{PM}_{2.5}$ may be that inhaled $\mathrm{PM}_{2.5}$ increases the generation of antigen-specific immunoglobulins, changes the airway reactivity toward antigens, or influences the ability of the lungs to deal with bacteria, which may account for the increased susceptibility to microbial infection such as that caused by M. pneumoniae [32]. Responses to $\mathrm{PM}_{2.5}$ via inflammatory mediators and oxidative stress represent an intricate mixture and may be relevant to the different materials absorbed in particles, such as metals, organic carbon, sulfates, nitrates, and other biogenic components [33]. For instance, mechanisms of oxidative stress induction and modulation of the host immune system and inflammatory responses via Tolllike receptors and/or the nuclear factor-kappa B pathway are postulated to be the result of $\mathrm{PM}_{2.5}$-associated metal complex interaction with M. pneumoniae [34]. Some of the components of $\mathrm{PM}_{2.5}$ that are deposited in the lung can be dissolved within seconds or minutes, while some of the dissolution processes can last for hours or days. Insoluble components can remain in the lung for months or even years, which may explain the impact of the lag time of $\mathrm{PM}_{2.5}$ in this study.

To a large extent, the generation of $\mathrm{PM}_{2.5}$ in developed countries can be traceable to anthropogenic sources. Predominant sources are the combustion of fossil fuels, biomass burning, and resuspended soil dust. In contrast, predominant sources of ambient $\mathrm{PM}_{2.5}$ in developing countries include vehicle emission and biomass smoke. In Shanghai, fuel emissions from mobile sources and exhaust emissions from industrial manufacturing account for most local sources. Considering their more frequent physical activity and longer time spent outside, children 
may have more access to ambient $\mathrm{PM}_{2.5}$ than adults. Children are one of the most susceptible groups to the effects of air pollutants. Higher respiratory rates undoubtedly result in a higher intake of air pollutants. Moreover, children's developing lungs may be less capable of handling toxic invasion because of their limited metabolic capacities. The increased susceptibility to $M$. pneumoniae can also be ascribed in part to their immature immune systems.

The analytic results of the single-pollutant models and multi-pollutant models demonstrated that the other air pollutants were not risk factors in our study. At the outset, the results of the single-pollutant models showed that $\mathrm{O}_{3}, \mathrm{SO}_{2}$, and $\mathrm{CO}$ seemed to be protective factors based on their association with pediatric hospital admissions for Mycoplasma pneumonia. However, after further analysis of all six air pollutants, $\mathrm{O}_{3}, \mathrm{SO}_{2}$, and $\mathrm{CO}$ were no longer potential protective factors. Consistent with our results of $\mathrm{O}_{3}$ in the single-pollutant models, $\mathrm{O}_{3}$ also displayed a paradoxical pattern in the analysis performed by de Souza and Nascimento [19]. The reason for this paradoxical pattern is unknown and requires further study.

The present study has several limitations. First, the Shanghai population data were obtained from only one institution, which might not be representative of the whole population of Shanghai. Second, exposure measurement errors resulting from discrepancies between the population-average exposure and atmospheric pollutant levels were unavoidable and might have incurred bias toward null and underestimated associations. Third, individuals' exposure to air pollutants was not taken into account. The exposure levels were deemed homogenous throughout the city. Fourth, we did not thoroughly investigate the possible association between indoor air pollution and Mycoplasma pneumonia in children. The latent influence of such pollution, which may be caused by house decoration, tobacco smoke, and strong oil fumes from cooking, may be underestimated. Fifth, although the time lag effects during the $M$. pneumoniae invasion period were taken into consideration, the admission day for Mycoplasma pneumonia in children might not be the first day that symptoms occurred. They may have previously received emergency treatment. This might have introduced bias. Erroneous diagnosis and double counting of the same patient may have also occurred. Further in-depth studies are needed to clarify the mechanisms underlying the potential association between pediatric Mycoplasma pneumonia and ambient air pollutants.

\section{Conclusions}

This study provided evidence of positive associations between elevated $\mathrm{NO}_{2}$ and $\mathrm{PM}_{2.5}$ concentrations and higher daily numbers of hospital admissions for $\mathrm{Myco}$ plasma pneumonia in children in Shanghai. Of all parameters studied, $\mathrm{NO}_{2}$ and $\mathrm{PM}_{2.5}$ had statistically significant associations with hospital admissions and might be risk factors for Mycoplasma pneumonia in children. The strength of the associations between the $\mathrm{NO}_{2}$ and $\mathrm{PM}_{2.5}$ concentrations and pediatric admissions for Mycoplasma pneumonia might be influenced by the levels of the above-described pollutants as well as the hysteresis effect. These findings indicate that the high incidence of Mycoplasma pneumonia in children in Asia might be attributed to the heavy air pollution in Asia. The results of our study highlight the imperative need for public health policies, especially in highly polluted areas in Asia. More vigorous actions to reduce the air pollutant levels are also in urgent need to protect and promote public health, particularly for children.

\section{Abbreviations \\ $\mathrm{Cl}$ : Confidence interval; $\mathrm{CO}$ : Carbon monoxide; $\mathrm{NO}_{2}$ : Nitrogen dioxide; $\mathrm{O}_{3}$ : Ozone; OR: Odds ratio; $\mathrm{PM}_{10}$ : Particulate matter (particles of $<10 \mu \mathrm{m}$ in aerodynamic diameter); $\mathrm{PM}_{2.5}$ : Fine particulate matter (particles of $<2.5 \mu \mathrm{m}$ in aerodynamic diameter); ppb: Parts per billion; $\mathrm{SO}_{2}$ : Sulfur dioxide}

\section{Acknowledgments}

The authors are grateful to all of the institutions that contributed to the data collection of our study, including the Pediatric Department of Shanghai Tenth People's Hospital, Jing'an District of Shanghai, China; the Shanghai Environmental Monitoring Center, China; the Shanghai Meteorological Service, China; and the National Bureau of Statistics, China.

\section{Authors' contributions}

ZW conceived and designed the study, gave the final approval of the version to be published, and is the corresponding author. NC drafted the manuscript, analyzed and interpreted the data, and is a co-first author. JS conceived and designed the study and is a co-first author. SC, NC, JS, JH, WY, $L G, R Y, R L, Z H Y, Q L$, and $Y Y$ contributed to the data interpretation, provided comments on the draft, and have read and approved the final version. All authors read and critically revised the manuscript and gave final approval of the version to be published.

\section{Funding}

This study was supported by the National Key Research and Development Program of China (2018YFC2000700), which provided the funding for the data analysis; the National Natural Science Foundation of China (71774116, 71603182, and 71804128), which provided the funding for the data sources; the Shanghai Municipal Planning Commission of Science and Research Fund (201740202); and the Shanghai Excellent Young Talents Project in Health System (2018YQ52), which provided the funding for the data collection.

\section{Availability of data and materials}

The datasets analyzed during the current study are available from the corresponding author on reasonable request and with permission of the related health department.

\section{Ethics approval and consent to participate}

The project was approved by the Ethics Committees of Tongji University and Shanghai Tenth People's Hospital (ref: LL-2016-ZRKX-017). Written informed consent was obtained from all the study participants. For participants under 16 years old, written informed consent was obtained from a parent or guardian. None of the patients' personal information included in the database was available to individuals who did not participate in the research.

Consent for publication

Not applicable. 


\section{Competing interests}

The authors declare that they have no competing interests.

\section{Author details}

'Department of Pediatrics, Shanghai Tenth People's Hospital, Tongji University School of Medicine, Shanghai 200072, China. ${ }^{2}$ School of Medicine, Tongji University, Shanghai 200092, China. ${ }^{3}$ School of Public Health, Shanghai Jiaotong University School of Medicine, 227 South Chongqing Rd, Shanghai 200025, China. ${ }^{4}$ Yangpu Hospital, Tongji University School of Medicine, Shanghai 200090, China. ${ }^{5}$ Navy 971 Hospital, Qingdao 266071, China. ${ }^{6}$ School of Economics \& Management, Tongji University, Shanghai 200092, China. ${ }^{7}$ General Practice Center, Nanhai Hospital, Southern Medical University, Foshan 528244, China.

Received: 31 July 2019 Accepted: 27 February 2020

Published online: 06 April 2020

\section{References}

1. World Health Organization: Pneumonia. http://www.who.int/news-room/ fact-sheets/detail/pneumonia (2016).

2. The committee for the Japanese Respiratory Society guidelines in management of respiratory infections. The Japanese Respiratory Society guideline for the management of community-acquired pneumonia in adults. Respirology. 2006:11(Suppl 3):79-133.

3. CLF W, Rudan I, Liu L, Nair H, Theodoratou E, Bhutta ZA, et al. Global burden of childhood pneumonia and diarrhoea. Lancet. 2013:381:1405-16.

4. Diaz MH, Benitez AJ, Winchell JM. Investigations of Mycoplasma pneumoniae infections in the United States: trends in molecular typing and macrolide resistance from 2006 to 2013. J Clin Microbiol. 2015;53:124-30.

5. Chen DM, Zhang YJ, Xu YJ, Shen TT, Cheng GR, Huang BK, et al. Comparison of chemiluminescence immunoassay, enzyme-linked immunosorbent assay and passive agglutination for diagnosis of Mycoplasma pneumoniae infection. Ther Clin Risk Manag. 2018;14:1091-7.

6. Miyashita N, Kawai Y, Akaike H, Ouchi K, Hayashi T, Kurihara T, et al. Macrolide-resistant Mycoplasma pneumoniae in adolescents with community-acquired pneumonia. BMC Infect Dis. 2012;1:126.

7. Liu PC, Xu MH, He LY, Su LY, Wang AM, Fu P, et al. Epidemiology of Respiratory Pathogens in Children with Lower Respiratory Tract Infections in Shanghai, China, from 2013 to 2015. Jpn J Infect Dis. 2018;71:39-44.

8. United States Environmental Protection Agency: Integrated Science Assessment (ISA) for Nitrogen Dioxide (Health Criteria). https://www.epa. gov/isa/integrated-science-assessment-isa-nitrogen-dioxide-health-criteria (2016).

9. NTT N, Amini H, Schindler C, Joss MK, Dien TM, Probst-Hensch N, et al. Short-term association between ambient air pollution and pneumonia in children: A systematic review and meta-analysis of time-series and casecrossover studies. Environ Pollut. 2017;230:1000-8.

10. Duan Z, Han X, Bai ZN, Yuan YD. Fine particulate air pollution and hospitalization for pneumonia: a case-crossover study in Shijiazhuang China. Air Qual Atmos Hlth. 2016:9:723-33.

11. Patto NV, Nascimento LFC, Mantovani KCC, Vieira LCPFS, Moreira DS Exposure to fine particulate matter and hospital admissions due to pneumonia: Effects on the number of hospital admissions and its costs. Rev Assoc Med Bras. 2016;62:342-6.

12. Croft DP, Zhang WJ, Lin S, Thurston SW, Hopke PK, Masiol M, et al. The Association between Respiratory Infection and Air Pollution in the Setting of Air Quality Policy and Economic Change. Ann Am Thorac Soc. 2019;16: 321-30.

13. Xu X, Wang GB, Chen N, Lu T, Nie S, Xu G, et al. Long-Term Exposure to Air Pollution and Increased Risk of Membranous Nephropathy in China. J Am Soc Nephrol. 2016;27:3739-46.

14. Ministry of environmental protection of the People's Republic of China. Ambient air quality standards (2012). http://kjs.mee.gov.cn/hjbhbz/bzwb/ dqhjbh/dqhjzlbz/201203/t20120302_224165.shtml (2016).

15. Lin S, Liu X, Le LH, Hwang SA. Chronic exposure to ambient ozone and asthma hospital admissions among children. Environ Health Persp. 2008:116. 1725-30.

16. Ostro B, Hu J, Goldberg D, Reynolds P, Hertz A, Bernstein L, et al. Associations of mortality with long-term exposures to fine and ultrafine particles, species and sources: Results from the California Teachers Study Cohort. Environ Health Persp. 2015;123:549-56.
17. Fan JC, Li SL, Fan CL, Bai ZG, Yang KH. The impact of PM2.5 on asthma emergency department visits: A systematic review and meta-analysis. Environ Sci Pollut R. 2016;23:843-50

18. Fann N, Lamson AD, Anenberg SC, Wesson K, Risley D, Hubbell BJ. Estimating the national public health burden associated with exposure to ambient PM2.5 and ozone. Risk Anal. 2012;32:81-95.

19. de Souza LSV, Nascimento LFC. Air pollutants and hospital admission due to pneumonia in children:a time series analysis. Rev Assoc Med Bras. 2016;62: 151-6.

20. Carvalho PC, Nakazato LF, Nascimento LFC. Exposure to NO2 and children hospitalization due to respiratory diseases in Ribeirao Preto, SP Brazil. Ciencia \& Saude Coletiva. 2018;23:2515-22.

21. Maclntyre EA, Gehring U, Molter A, Fuertes E, Klumper C, Kramer U, et al. Air Pollution and Respiratory Infections during Early Childhood: An Analysis of 10 European Birth Cohorts within the ESCAPE Project. Environ Health Persp. 2014;122:107-13.

22. Lu C, Deng QH, Yu CWF, Sundell J, Ou CY. Effects of ambient air pollution on the prevalence of pneumonia in children: Implication for National Ambient Air Quality Standards in China. Indoor Built Environ. 2014;23:25969.

23. LV CG, Wang XF, Pang N, Wang LZ, Wang YP, Xu TF, et al. The impact of airborne particulate matter on pediatric hospital admissions for pneumonia among children in Jinan, China: A case-crossover study. J Air Waste Manage. 2017:67:669-76.

24. Jiang W, Lu C, Miao YF, Xiang YG, Chen L, Deng QH. Outdoor particulate air pollution and indoor renovation associated with childhood pneumonia in China. Atmos Environ. 2018;174:76-81.

25. Berglund $M$, Boström C-E, Bylin G, Ewetz L, Gustafsson L, Moldéus $P$, et al. Health risk evaluation of nitrogen oxides. Exposure. Scand J Work Env Health. 1993;19(Suppl 2):14-20.

26. United States Environmental Protection Agency: Policy Assessment for the Review of the Primary National Ambient Air Quality Standards for Oxides of Nitrogen. (1993) https://www.epa.gov/sites/production/files/2017-04/ documents/policy_assessment_for_the_review_of_the_no2_naaqs_-_final_ report.pdf.

27. Commission of the European Communities: A preparatory study for establishing criteria (dose/effect relationships) for nitrogen oxides. (1976) https://core.ac.uk/download/pdf/16514827.pdf.

28. Transportation Research International Documentation: Atmospheric pollution from vehicle emission: at four sites in Coventry. (1976) https://trid. trb.org/view.aspx?id=43509.

29. Svartengren M, Strand V, Bylin G, Jarup L, Pershagen G. Short-term exposure to air pollution in a road tunnel enhances the asthmatic response to allergen. Eur Respir J. 2000;15:716-24.

30. Belleudi V, Faustini A, Stafoggia M, Cattani G, Marconi A, Perucci CA, et al. Impact of Fine and Ultrafine Particles on Emergency Hospital Admissions for Cardiac and Respiratory Diseases. Epidemiology. 2010;21:414-23.

31. de Grubb MCM, Kilbourne B, Kilbourne K, Langston M, Gittner L, Zoorob RJ, et al. Socioeconomic, environmental, and geographic factors and US lung cancer mortality, 1999-2009. Family Med Commun Health. 2017:5:3-12.

32. Zanobetti A, Schwartz J, Gold D. Are there sensitive subgroups for the effects of airborne particles? Environ Health Persp. 2000;108:841-5.

33. World Health Organization: Air quality guidelines. Global update 2005. In: Particulate matter, ozone, nitrogen dioxide and sulfur dioxide; 2006. http:// www.euro.who.int/_data/assets/pdf_file/0005/78638/E90038.pdf.

34. Hou W, Xu XJ, Lei $\overline{Y G}$, Cao JJ, Zhang $\bar{Y}$, Chen L, et al. The role of the PM2.5associated metals in pathogenesis of child Mycoplasma Pneumoniae infections: a systematic review. Environ Sci Pollut R. 2016;23:10604-14.

\section{Publisher's Note}

Springer Nature remains neutral with regard to jurisdictional claims in published maps and institutional affiliations. 